\title{
Enhanced the Farmers Income through Improved Cultivation Practices of Lowland Rice under Longleng District of Nagaland: A Success Story
}

\author{
Manoj Kumar ${ }^{1,2 *}$, K. L. Meena ${ }^{1}$ and D. J. Rajkhowa ${ }^{3}$ \\ ${ }^{1}$ Krishi Vigyan Kendra, Longleng, Nagaland, India \\ ${ }^{2}$ Krishi Vigyan Kendra, East Sikkim, Ranipool, Sikkim, India \\ ${ }^{3}$ ICAR RC for NEH Region, Nagaland centre, Jharnapani, Nagaland, India \\ *Corresponding author
}

\section{Keywords}

Improved practices,

Rice, Yield,

Economics

\section{Article Info}

Accepted:

18 August 2020

Available Online:

10 September 2020

\section{A B S T R A C T}

Longleng district falls under the subtropical hill zone of Eastern Nagaland. Agriculture is the main stay of the people, in which Low land (Pani Kheti) is one of them for their livelihood. Farmers of the district practiced traditional rice cultivation with low yield after maximum inputs due to lack of knowledge of improved cultivation practices. Therefore, Krishi Vigyan Kendra (KVK) took initiative to replace the farmers' practices through disseminations of improved technology for enhancing the productivity and income. Before the intervention of new technology, awarness -cum- training programme on lowland rice was organised in the village. All together 16 nos. of farmers were participated in the training programme and took interest for adopt the improved practices. After that hand on training programme of nursery sowing, transplanting was conducted at farmers' field during the year 2014-15 to 2016-17. Results of improved practiced found that average yield ( 3 years) was recorded $44.76 \mathrm{q} / \mathrm{ha}$ against $32.40 \mathrm{q} / \mathrm{ha}$ with farmers practices. Net profit and B:C ratio were recorded Rs.33210/ha, Rs.19080/ha and 2.62, 1.96 with improved and farmers practices respectively. Percentage increase yield and net profit were 38.2 and $73 \%$ with improved practice as compared to tradition cultivation. The successful demonstration on low land rice is by following the principles of "learning and doing" and "seeing and believing". After the successful intervention of technology, farmers growing new intervention technology of rice cultivation. The impressive performance of the technology awankened the farmers, farm women of the village and neighbouring villages to adopt this technology helps to increase the net income of the farmers.

\section{Introduction}

Rice is main staple food crop of North East India and occupying an area of $\sim 3.5 \mathrm{~m} \mathrm{ha}$, which account $\sim 7 \%$ of the area and $6.5 \%$ of the country rice production (Kumar et al., 2017). The productivity of rice in NE states is 2.15 $\mathrm{t} / \mathrm{ha}$, is much below than average national a productivity of rice $2.58 \mathrm{t} / \mathrm{ha}$ (Agricultural statistics, 2018). In context to Nagaland, rice is primary food and cultivated in an area of $\sim 21.2$ thousand ha and producing 42.4 thousand tonnes with a productivity of 2.0 t/ha (Anonymous, 2018). Longleng district in the states fall under most backward as per classified by planning commission of 
India. The livelihood of the people largely depends on agriculture production system and rice is the stable food in the region and cultivated in an area of $\sim 8.57$ thousand ha with the production of 19.38 thousand tonnes and productivity $\sim 2.26$ t/ha (Anonymous, 2018). Farmers of the district practiced traditional rice cultivation with low yield after maximum inputs (seeds and labour) and are not even able to meet their food requirement due to the lowest productivity of rice. The main problems associated with lower productivity of rice due to lack of knowledge about the improved cultivation practices. Therefore, the Krishi Vigyan Kendra Longleng took the initiative and conducted a demonstration programme during the three consecutive kharif season of the year 2014 to 2016 to replace the farmers practice with improved cultivation practices in lowland rice for achieving optimum productivity and profitability of the poor tribal farmers of Longleng District.

\section{Materials and Methods}

Field demonstration was conducted at farmer's field of Krishi Vigyan Kendra, Longleng, ICAR- Research Complex for North Eastern Hill Region, Nagaland Centre Jharnapani, Medziphema during the three consecutive kharif seasons of 2014-15 to 2016-17. The field was located between at $26^{0}$ 26' 0' N Latitude, 940 52' 0' E Longitude with altitude of $1366 \mathrm{~m}$ above mean sea level. Soil of the experimental field was sandy loam and acidic in reaction ( $\mathrm{pH} 5.3$ ), high in organic carbon $(0.91 \%)$, low in available $\mathrm{N}$ (302 kg/ha) and medium in available $\mathrm{P}$ (12.8 $\mathrm{kg} / \mathrm{ha})$ and $\mathrm{K}(280 \mathrm{~kg} / \mathrm{ha})$. Mean monthly average temperatures of three years were varying from $27.64^{\circ} \mathrm{C}$ to $29.85^{\circ} \mathrm{C}$ and $16.54^{\circ} \mathrm{C}$ to $21.09^{\circ} \mathrm{C}$ during the year of 2014 2016, respectively (Fig. 1). Total rainfall received during the cropping period (May October) was $1945.8 \mathrm{~mm}, 2192.6 \mathrm{~mm}$ and
$1096 \mathrm{~mm}$ in 2014, 2015 and 2016, respectively and average rainfall (3 years) was $1744.8 \mathrm{~mm}$. However, the rainfall distribution over month was better in 2015 as compare to 2014 and minimum rainfall was received in 2016. The monthly rainfall was recorded maximum in month of August 2014 and August 2015. Whereas, maximum rainfall was recorded higher in the month of July, 2016. Baseline survey was conducted in the Pongching village before the intervention of improved cultivation practices of rice. It was found that farmers using more seed rate (40$50 \mathrm{~kg} / \mathrm{ha})$, seedling age (30 - 40 days for transplanting, more seedling per hill (6-8 nos. /hill) along with less spacing $(10 \times 10 \mathrm{~cm})$ and therefore getting low yield. A intervention was taken up with improved cultivation practices such as seed rate $(20 \mathrm{~kg} / \mathrm{ha})$, seedling age (15-20 days), spacing $(20 \mathrm{~cm} \mathrm{x}$ $20 \mathrm{~cm})$ and nos. of seedlings (2-3/ hill). Before the intervention of new technology, awarness -cum- training programme on lowland rice was organised in the village. All together 16 nos. of farmers were participated in the training programme and adopted the intervention of improved technology. After that demonstration was conducted on nursery management and transplanting of rice at farmers field during the year 2014-15 to 2016-17 covering an area of 4.5 ha. Farmers fields was regularly monitored of by the agronomy scientist during the crop cycle. Two hand weeding were given at 20 and 45 days after transplanting (DAT). Neem oil @ $3 \mathrm{ml}$ per litre of water during the flowering stage for controlling the insect and no disease was appeared during the cropping cycle. Five plants were randomly selected in each demonstration to record the observation on growth and yield parameters. Data collected on plant height, tillers $/ \mathrm{m}^{2}$, grains/panicle, panicle length, panicle weight and 1000-grain weight were recorded at crop maturity. Grain yield was recorded and convert into $\mathrm{q} / \mathrm{ha}$ during all the years of demonstration. In 
economics, cost of cultivation was taken into account for calculating economics of practices as work out net return per ha and benefit cost ratio. The gross returns were taken as income from produce of grain yield based on prevailing price. Net return and benefit cost ratio was calculated with the help of following formula:

Net return $\left(\mathrm{ha}^{-1}\right)=$ Gross return $\left(\mathrm{ha}^{-1}\right)-$ cost of cultivation $\left(\mathrm{ha}^{-1}\right)$

Benefit : cost ratio $=\frac{\text { Grain yield }}{\text { Biological }(\text { Grain }+ \text { Straw }) \text { yield }}$

Production efficiency and economic efficiency (Kumar et al., 2017) were calculated with the help of the formula.

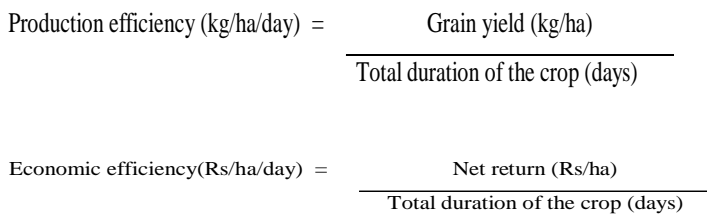

\section{Results and Discussion}

Growth, yield parameters and economics were presented in the table 1 . Results revealed that the plant height was recorded $115.2 \mathrm{~cm}$ and $96.4 \mathrm{~cm}$ with improved and traditional practices respectively. Yield attributes such as Panicle $/ \mathrm{m}^{2}$, Panicle length, Panicle weight and Test weight were recorded 146, $21.2 \mathrm{~cm}$ $4.2 \mathrm{~g}, 30.2 \mathrm{~g}$ and $116,18.8 \mathrm{~cm}, 3.6 \mathrm{~g}, 28.6 \mathrm{~g}$ under improved and traditional practices respectively. Grain yield was recorded 42.50, $45.30,46.50 \mathrm{q} / \mathrm{ha}$ with improved practices during the year 2014-15, 2015-16 and 201617 respectively. Whereas, grain yield was obtained 31.9, 33.2, 32.10 q/ha under traditional practices (Fig. 2). Maximum mean rice grain yield (3 years) was recorded 44.76 $\mathrm{q} / \mathrm{ha}$ with improved practices, which was 38.14 percent higher than traditional practices (32.40 q/ha). Net profit and B:C ratio were recorded Rs.33210/ha, Rs.19080/ha and 2.62, 1.96 with improved and farmers practices respectively. Percentage increase of net profit was found $74 \%$ higher with improved practice than traditional cultivation practices. Production efficiency was recorded 34.92, $\mathrm{kg} / \mathrm{ha} /$ day and $24.10 \mathrm{~kg} / \mathrm{ha} /$ day under improved and farmers practices respectvely, whereas economic efficiency was also found higher (258.75 Rs/ha/day) in improved practices as compared to farmers practices (141.33 Rs/ha/day).

Table.1 Different parameters of traditional \& improved rice cultivation (mean 3 years)

\begin{tabular}{|l|c|c|}
\hline Parameters & Traditional & Improved \\
\hline Plant height (cm) & 96.4 & 115.2 \\
\hline Panicle/m2 & 116 & 146 \\
\hline Panicle length (cm) & 18.8 & 21.2 \\
\hline Panicle weight (g) & 3.6 & 4.2 \\
\hline Test weight (g) & 28.6 & 30.2 \\
\hline Net Income (Rs/ha) & 19080 & 33120 \\
\hline B:C ratio & 1.96 & 2.62 \\
\hline Production efficiency (kg/ha/day) & 24.10 & 34.92 \\
\hline Economic Efficiency(Rs/ha/day) & 141.33 & 258.75 \\
\hline
\end{tabular}


Fig.1 Rainfall, the maximum and minimum temperature of the cropping period (mean 3 years)

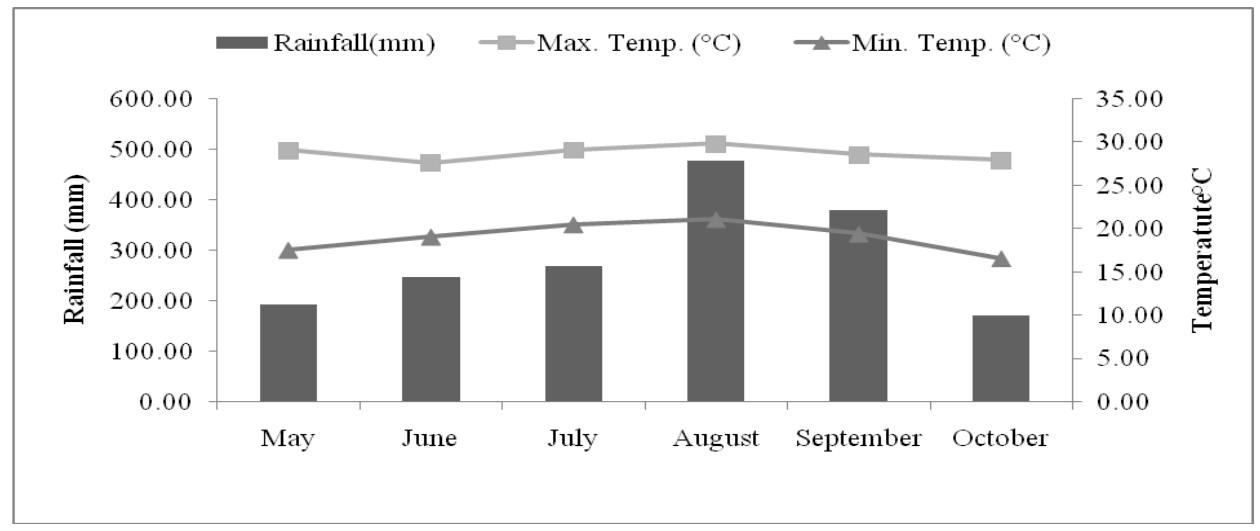

Fig.2 Rice grain yield of traditional \& improved rice cultivation (mean 3 years)
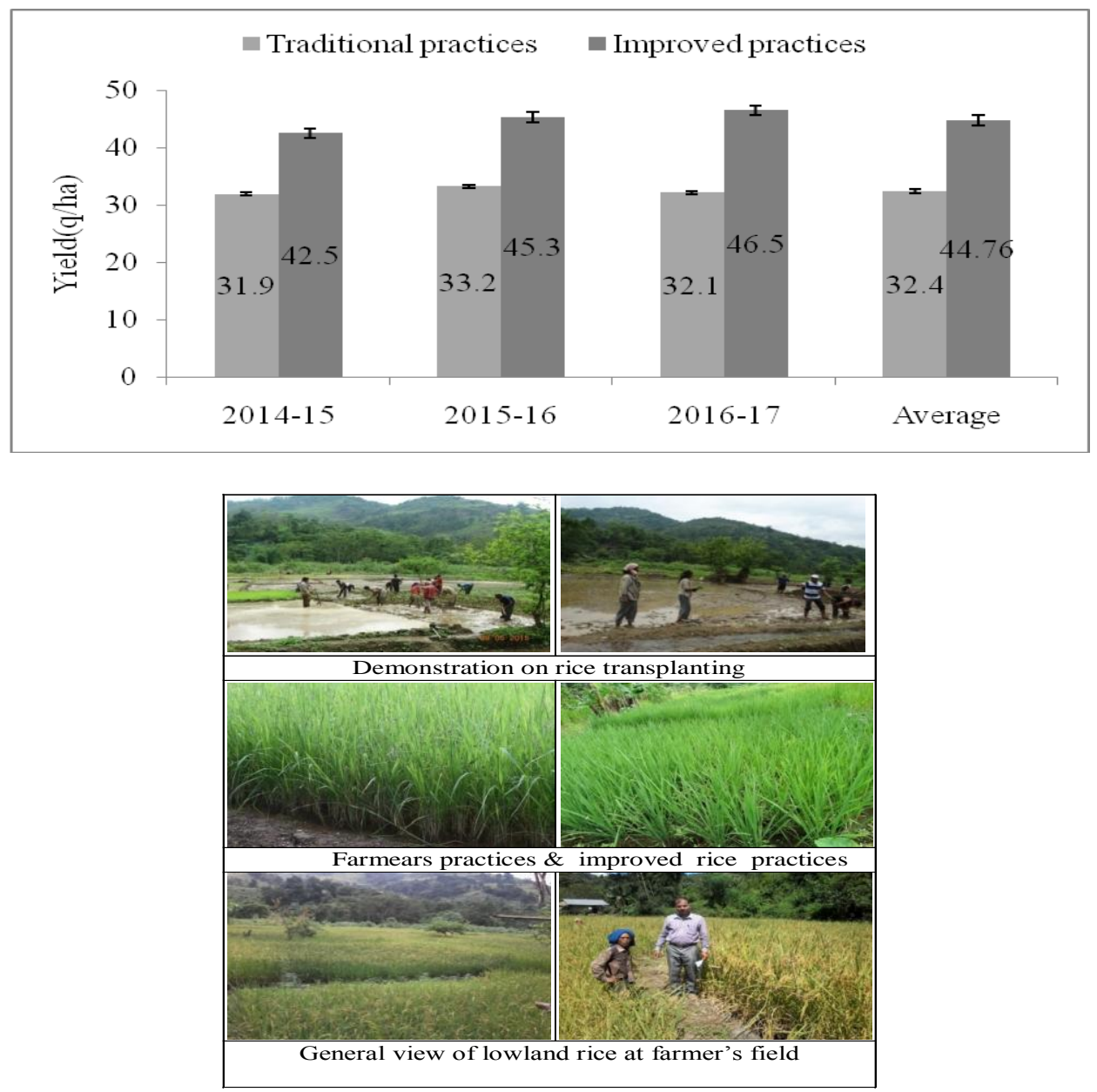

All the growth and yield parameters was recorded higher in improved practice than optimum environment condition suited for farmers practice. This might be due to improved rice cultivation practices, which helps for better root development and 
ultimately increase the growth and yield attributes. Higher grain yield of rice might be due to the higher productive tiller/plant and higher number of grain per panicle. Thus, the FLD might have a positive impact on farming community in the district over local practices. Similar results were also reported by Mondal et al., (2005), Kumar et al., (2017) and Samant (2014) in rice crops.

In conclusion the successful demonstration on lowland rice by following the principles of "believing through seeing" and "learning by doing". After the successful intervention of technology, farmers was adopted new technology of improved rice cultivation. The impressive performance of the technology awankened the farmers, farm women of the village and neighbouring villages to adopt this technology helps to increase the elevate net income of the farmers.

\section{References}

Anonymous.2018.Hand book of Agriculture, Govt. of Nagaland

Agricultural Statistics at a glance 2018 . Ministry of Agriculture \& Farmers Welfare Department of Agriculture, Cooperation \& Farmers Welfare

Kumar R, Chatterjee D, Deka B.C and Ngachan S.V. 2017.Validation of common salt application on productivity, profitability, nutrient uptake and soil health of upland rice
(Oryza sativa L.) under shifting cultivation area of Nagaland. Indian Journal of Traditional Knowledge 16 (2): 341-349.

Kumar Manoj, Kikon E. Lireni., Meena K. L., Baishya, L. K., and Rajkhowa D. J. 2017. Enhancement the productivity and income through improved practices of low land rice under Longleng District of Nagaland. Published in national seminar on smart farming for enhancing input use efficiency, income and environment security (SFEIES 2017) during September19-20, 2017 at ICAR Research Complex for NEH Region, Umiam, and Meghalaya. Page: 285.

Kumar Manoj, Rajkhowa D. J., Meena K. L., Kumar, Rakesh., Zeliang, K Patu., Kikon E. Lireni., Rangnamei, K Lily and Namei, A. 2017. Effect of nutrient management of Low land rice for improving productivity, profitability and energetic under the mid hills of Nagaland. Journal of Agrisearch 4(4):247-250

Samant T.K., 2014. Evaluation of front line demonstration on rice (Manaswini). Agricultural Update. 9(3):311-315

Mondal, M.M.A, Islam, A.F.M.S. and Siddique, M.A. 2005. Performance of 11 modern transplant aman cultivar in the northern region of Bangladesh. Bangladesh J. Crop Sci., 16: 23-29.

\section{How to cite this article:}

Manoj Kumar, K. L. Meena and Rajkhowa, D. J. 2020. Enhanced the Farmers Income through Improved Cultivation Practices of Lowland Rice under Longleng District of Nagaland: A Success Story. Int.J.Curr.Microbiol.App.Sci. 9(09): 1853-1857.

doi: https://doi.org/10.20546/ijcmas.2020.909.233 